
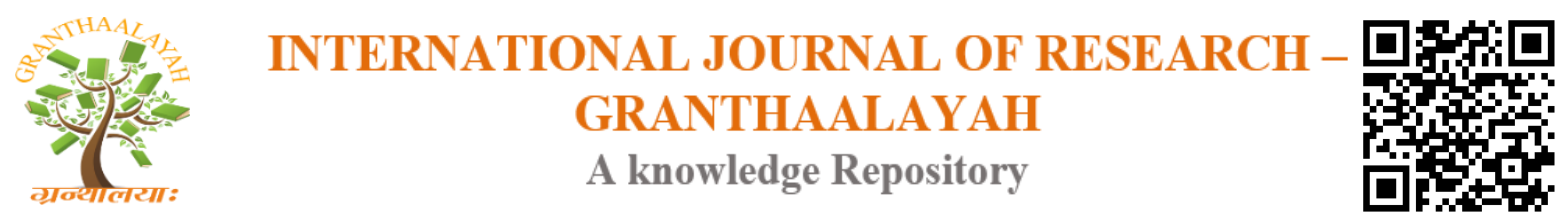

Science

\title{
SUSTAINABILITY AND DEMOCRATIC SCHOOL MANAGEMENT
}

\author{
Joel Haroldo Baade *1, Adelcio Machado dos Santos ${ }^{2}$, Levi Hulse ${ }^{3}$, Vera Lúcia Simão ${ }^{4}$, \\ Joel Cezar Bonin ${ }^{5}$, Rosana Claudio Silva Ogoshi ${ }^{6}$ \\ *1, 2, 3, 6 Postgraduate Program in Society and Development, Alto Vale do Rio do Peixe University \\ (ARPUNI), Brazil \\ ${ }^{4,5}$ Postgraduate Program in Basic Education, Alto Vale do Rio do Peixe University (ARPUNI), \\ Brazil
}

\begin{abstract}
Motivation/Background: Sustainability is established on economic, environmental and social pillars, which are understood as inseparable. This demands changes of paradigms and the construction of new models of living, which are directly connected to education. In this context, assuming that people's actions are more dependent on consolidated habits than on conscience, this essay hopes to demonstrate that democratic management is an irrevocable imperative towards a sustainable society.

Method: Methodologically, the research is of a standard nature, as we used qualitative, descriptive and exploratory approaches. As for the procedures, it can be classified as a bibliographic and documental research study.

Results and Conclusions: It was concluded that democratic management in education is of great importance for the consolidation of the paradigm of sustainability since schools have a key role in the formation of citizens.
\end{abstract}

Keywords: Sustainability; Education; Democratic Management.

Cite This Article: Joel Haroldo Baade, Adelcio Machado dos Santos, Levi Hulse, Vera Lúcia Simão, Joel Cezar Bonin, and Rosana Claudio Silva Ogoshi. (2019). "SUSTAINABILITY AND DEMOCRATIC SCHOOL MANAGEMENT." International Journal of Research - Granthaalayah, 7(9), 39-46. https://doi.org/10.29121/granthaalayah.v7.i9.2019.555.

\section{Introduction}

The discussion about sustainability is more than a theory; it is a change in paradigm. It is also more than a concern over matters of the ecological and environmental order, but founded on changing ones way of life for it affects all spheres of human life, economic, social and environmental.

Since sustainability is of such vital importance, it cannot be disconnected from education and specifically from the determinant management model of educational organizations for they are crucial for the type of education carried out in the classroom. Therefore, this essay aims to 
demonstrate that democratic management is an irrevocable imperative in building a sustainable society.

The text is structured in three topics. First, we approach the concept of sustainability, highlighting its tripod: economy, ecology and society. Second, we approach central elements of the democratic principle. At last, democratic management is analyzed as a determinant factor for education that is developed in educational institutions. Methodologically, the research is of a standard nature, as we used qualitative, descriptive and exploratory approaches. As for the procedures, it can be classified as a bibliographic and documental research study.

\section{Sustainability}

The idea of sustainability or sustainable development is based on three pillars: economic development, environmental protection and social inclusion (PEREIRA, 2009).

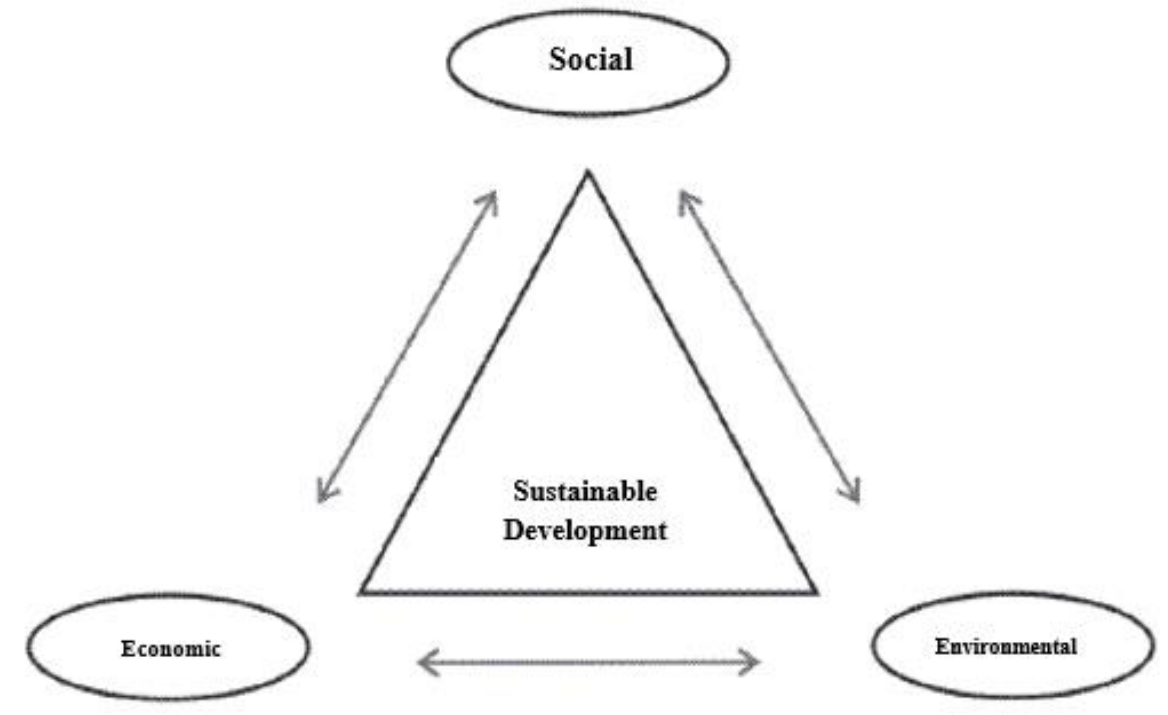

Figure 1: Pillars of sustainable development

Source: PEREIRA, 2009, p. 119.

These pillars are inseparable when it comes to the conception of what we understand as a sustainable development; as a result, none can be thought of as alien or independent from the others. Thus, from a perspective of sustainability, one could not think of economic development apart from social or environmental development. Moreover, it is not possible to think of environmental and social developmental without considering the possibility of economic development.

The concept of sustainability was developed in the second half of the 20th century, when pioneer research studies demonstrated the hazardous effects of $\mathrm{CO} 2$ emissions in the atmosphere as well as environmental hazards caused by the indiscriminate use of insecticides. In this trajectory, the founding of the Club of Rome in 1968 and the coining of the term "eco-development" at the Stockholm Conference in 1972 (PEREIRA, 2009; LOBE JUNIOR, 2014) is notable. The most important contribution of the Club of Rome to the definition of the concept of sustainable 
development was the document The Limits of Growth, also published in 1972, which became more known as the "Meadows Report," due to the surname of two of its three researchers. The document has decisively helped overcome romanticized and less rigorous views of criticism of environmental depredation (LOBE JUNIOR, 2014).

It can be concluded that the concept of sustainability is based on a principle of interdependence, which can be connected to a democratic principle. This is further reinforced by the idea that there is no hierarchy between the elements that make up the tripod of sustainability.

\section{The Democratic Principle}

In its origins, the structures of public agencies responsible for education had directives established by the federal government. It determined a single model of organization of public management in the country, thus reflecting the political dimension of dominance prevailing in economic, ideological and repressive State apparatuses. These public agencies responsible for education have recently gone through a process of reformulation of their organizational structures. This reformulation has introduced, as a base, the ideas of "decentralization" and "participation" (BRASIL, 2004).

Concerning participation - mainly of education policy managers, supervisors and teachers - it was a failure, since those agents did not have enough time to recognize and discuss the changes proposed by the educational systems. However, participation strategies should not only encompass participation in decision-making, but also foster connection with local members. By doing so, all would be involved in school management through a critical and decisive participation in the educational process that should be adopted, thus overcoming the separation between pedagogical planning and action.

The concept of participative management entails the idea of participation, that is to say, the joint work of people analyzing situations and deciding how to proceed. When referring to educational systems, the concept of participative management involves - in addition to teachers and staff parents, students and any community representative who is interested in school improvement and effectiveness (BORDIGNON; GRACINDO, 2004).

Authoritarianism, bureaucratization and centralism represent obstacles to the existence of organization, effectiveness and, therefore, management and supervision aimed at improving educational systems. In order for democratic management (that is, community participation in the administration of educational institutions) to take place concretely, greater autonomy is required.

Bobbio (1987) affirms that democracy is a dynamic phenomenon that is naturally in constant transformation; moreover, it is consecutively reinvented and, for that reason, established as evolutive.

Historically conceived as the governance of the citizens, as power from the people and for the people, full democracy is distinctly divided and complemented as Direct Democracy or Representative Democracy. Direct Democracy acts under the guise of universal adhesion. Although Representative Democracy considers individual differences and singularities to be 
complacent, it is pluralist. It is run by collective representatives, who are held accountable for their actions. Ergo, transparency and visibility become sine qua non qualities for the constitution of a democratic regime.

\section{Democratic School Management}

Starting from these assumptions, according to the warnings of Paro (1997), whenever a participative educational management is proposed - with an effective participation of parents, educators, students and school staff -, it is labeled a defect of utopia. For Paro (1997), it is necessary to reform our current school systems. This transformation, in Paro's words, fundamentally demands the presence of the educational community in the management model.

In that sense, it is necessary to modify the authority system and redistribute work within the school context. Returning to the thoughts of Bobbio (1987), he affirms that, in democracy, the individual is primarily considered and seen from their role as a citizen, not from their multiple roles.

The extension of the democratization process reveals itself as an ascending power, that is, in the transition from political democracy to social democracy. Democracy is therefore characterized by a set of rules that establish who is authorized to adopt collective decisions and by what procedures. Collective decisions may be circulatory for the entire group, i.e. they are adopted by most people, which is a fundamental rule. Currently, we have a set of elements in school hierarchy, which supposedly delegate all power to the principal. Ultimately, it is not enough to elect a principal, nor to have a contest for the position. Permanent participation legitimizes decisions, since the elected principal may act with authoritarianism (PINTO, 1995).

In light of Cury's teachings (2000), at times when popular classes exerted pressure on power systems, it is common to identify the struggle for education, which becomes an expression of classes. According to the author, it does not mean that there is a historical constancy, nor that the ruling class does not use its power to disassemble certain schooling methods even in an inclusive educational sphere.

Authoritarianism, paternalism and nepotism - as seen by scholars and specialists of various tendencies and according to D'Angelo (1995) -, are secular phenomena intrinsic to Brazilian culture. In other words, they have been rooted for centuries in the cultural sphere. These characteristics underlie social, political and administrative procedures as well as different spheres and areas of knowledge. Consequently, this conduct is manifested in relationships between individuals and groups.

Relationships within institutional contexts - specifically in educational institutions and in a society characterized as such - lead the individual to present behaviors directed to obedience, fear and submission (CANIVEZ, 1998). There is an urgent need for education towards participation. Unless we engage in pedagogical actions to liberate individuals from behaviors directed to protection and obedience, participation will not be fully achieved.

Currently, it is observed that principals, before being educators committed to students' education, are faced with situations in which they simply need to give orders, get involved in bureaucratic 
work behind desks, sign documents of no importance for education, clean and organize the school and are forced to carry out educational programs that often do not take into account the realities and necessities of that educational community.

The construction of a democratic school is a project that is not plausible without the active participation of students and teachers; moreover, the participation of other sectors and the active citizenship of other agents are also presupposed. Therefore, this project is not feasible without the cooperation of the community as a whole (PINTO, 1995).

It should be highlighted that a participative democracy leads the population to achieve increasingly higher levels of decisive participation, thus ending the hierarchical division of functions between those who plan and decide and those who execute the tasks and suffer the consequences of those decisions (CANIVEZ, 1991).

Bordenave (1994) declares that a greater participation of the school in the community would bring some benefits such as:

- It would reduce the distance that often exists between the school and the world of work;

- It would increase the efficient use of places such as factories, workshops, farms etc. as places of learning;

- It would increase inter-learning between various productive sectors of the community;

- It would increase the educational reach of school among adults.

The administrative autonomy of school managers is very limited, which prevents them from taking any action directed to the rationalization of resources and to the participation of other sectors of society. However, these are not unattainable actions.

In addition to the usual institutional bureaucracy, there is a more harmful element present in school contexts: the presence of some overtly bureaucratic principals, who only work to demand the fulfillment of established rules and norms. At other times, their main goal is to create new norms and procedures, which make processes become even more obstructed (ALVAREZ ESTRADA, 2012).

In theory, the school as a social organization provider of services should have as the main objective of its mission, the guiding of its profile of action in relation to society. However, this action has been the object of constant criticism from diverse public-school agents, who have distinct aspirations, demands and claims. On the one hand, there are the users (clients) who see school as part of the universe where bureaucracy prevails, with high costs, constant waste of resources and low productivity, in addition to the questionable quality of the product that is offered. On the other hand, there is the market that provides the school with the supplies required to the development of its activities, which also presents several complaints.

Brazilian society has gone through advances and setbacks concerning democratic participation. There have always been times when the capacity to stimulate significant change in power relations is intensified in all areas of political action. At such times, the procedures become more open and democratic within the global society, meanwhile a profile of democratization is built in private spheres, principally concerning education. This convergence determines that the educational 
policy and praxis in schools assimilate the process and designate possibilities so that democratic manifestation is achieved in every Brazilian citizen. However, this is not a rule, since new authoritarian models emerge in the dynamics of a complex society.

The democratization of schools has been evaluated from three aspects, according to the perception of official agencies or yet in the perspective of educators, especially the ones who are more critical when analyzing the educational process: democratization as a way of increasing access to educational institutions, democratization of pedagogical processes and democratization of administrative processes.

It is crucial to understands that the process of school democratization fundamentally demands the reception of these three aspects, whereas school administration, under the capitalist regime, is not a function that has autonomy concerning the economic, political and social situation in so far as school principals are not part of the educational planning. They do not organize pedagogical activities, nor are they involved in the development of educational policies.

However, according to Paro (1997), it is said that the management must fundamentally seek the participation of the whole community. Nonetheless, community participation in school administration finds many obstacles before it can really happen; for that reason, people who intend to work towards this participation should be convinced of the relevance and necessity of this project so that they do not abandon the plan in the face of beginning difficulties.

The growing prominence of the indispensability of popular participation in instances where services are offered by the State seems to be in the confirmation of the fragility of liberal democracy, which restricts the participation of a great part of population in elections thus preventing them from participating in processes that, along the five or four years of the mandate, would allow them to control the actions of governing authorities in order to meet the interests of the working class. Based on the above-mentioned evidence, effective democracy is said to determine the democratic control of the State. In the contemporary reality, the great masses of the population have no control over the actions of the State; as a consequence, the promotion of techniques able to make this control viable is urgent.

School will be genuine only when people have general and equal access to good school education. That can only be assured by the democratic control of the school. Therefore, based on all evidence, it is concluded that participation is the basis for the universalization of a high quality education and, consequently, for the construction of a sustainable society.

It is important to highlight that community participation in the school, as it is seen in all democratic process, happens along the journey, which does not extinguish the need to reflect in advance on the obstacles and possibilities that are presented by the reality when we think about certain actions. Basically, when the highest ranking position in the school depends almost exclusively on a contest that aims at measuring the administrative competence of the candidate without any direct connection with the interests of school users. The inflation of the technical covers up the necessarily political nature of the problem. 
By implying reciprocal collaboration between groups and people, democracy is a holistic procedure that should involve all aspects of the personality of every individual. There can be no full democracy without democratic people to exert it; in that sense, the reality of our schools falls far short of meeting the requirement implied in this premise. It is not just about organizational and management structures, nor is it about the election of principals and other staff, the access to school and the students' scholarly triumphs, the pedagogy, the organization of work in school, the curriculum and the evaluation. In the public school as in the workplace, its forms of civic and sociocultural interference in and with the community represent some of the crucial elements on which this democratization depends.

However, those elements represent constitutional features of a democratic school governance, laboriously achievable in a centralized and autocratic supra-organizational administration that is not committed to school autonomy as a locus of significance of policies.

Regarding its different dimensions, the democratization of the administration is not only a catalyst or instrumental factor to build an autonomous, sustainable and democratic school. In the same way it is a value in itself, which can allow and reinforce the democratization of structures and processes of school management through its continuous affirmation and updating.

Based on these thoughts and considering legitimate the discussion and negotiation, interests and projects, crisis and conflicts between the educational organization in its local and communitarian context and the different political-administrative levels that make up the educational system, the following inferences can be drawn. It is not about outlining well-defined preferences or considering that the democratization of the school organization will only be possible after the previous democratization of the administration of the educational precept. In fact, both are implicated, but it is likely that, at a certain point one may present better results if compared to the other, and it is also acceptable that the initiative of one can positively influence and promote the transformation of the other.

However, it is not advisable to accept complete lack of cooperation and constant disconnection between them, such as to build a democratic and autonomous school organization in the reality of an authoritarian and centralized administration or, on the contrary, to recognize the existence of a democratic, participative and decentralized administration in an educational system formed by educational units whose organization and management do not work towards participation.

\section{Conclusions and Recommendations}

In that sense, it is urgent to create a space for debate, both for the evaluation and for the analysis of situations experienced in daily life, aiming to make sustainability compatible with daily life. Therefore, this is a primary and powerful step towards an exchange of experiences and an effective collaboration between researchers and other people, in addition to encompassing the systematization of multiple practices.

Finally, it should be noted that sustainability refers to methods of development that are economically viable, environmentally friendly and socially just, besides being able to guarantee benefits to humanity and to other forms of life in our planet. In these terms, sustainability is closely 
related to the democratic principle, as both seek to equate what is often seen as opposite. Sustainability and democracy presuppose some divergence and the need for equation, not necessarily uniformity.

For this reason, advances in sustainability, in many ways, also depend on the achievement of a more democratic school management. Therefore, further studies on sustainability and democracy are needed, since these concepts have the potential for mutual enrichment.

\section{References}

[1] Alvarez Estrada, A. Burocracia e educação: considerações preliminares. Revista Iberoamericana De Educación, 60(2), 5, 2012. https://doi.org/https://doi.org/10.35362/rie6021319. Accessed 12/07/2019.

[2] BOBBIO, Norberto. O futuro da democracia: uma defesa das regras do jogo. Rio de Janeiro: Paz e Terra; 1987.

[3] BORDENAVE, Juan E. Diaz. O que é participação? São Paulo: Brasiliense; 1994

[4] BORDIGNON, G.; GRACINDO, R. V. Gestão da educação: o município e a escola. In: FERREIRA, N. S. C.; AGUIAR, M. A. da S. Gestão da Educação: impasses, perspectivas e compromissos. São Paulo: Cortez; 2004

[5] BRASIL. Ministério da Educação. Secretaria de Educação Básica. Programa Nacional de Fortalecimento dos Conselhos Escolares. Gestão da educação escolar. Brasília: UnB, CEAD; 2004.

[6] CANIVEZ, Patrice. Educar o cidadão? Campinas: Papirus; 1991.

[7] CURY, Carlos R. Jamil. Educação e contradição. São Paulo: Cortez; 2000.

[8] D’ANGELO, Hamilton. Introdução à gestão participativa. São Paulo: STS; 1995.

[9] HORA, Dinair Leal da. Gestão democrática na escola: artes e ofícios de participação coletiva. Campinas: Papirus; 1994.

[10] PARO, Vitor Henrique. Gestão democrática da escola pública. São Paulo: Ática; 1997.

[11] LIMA, Licínio C. Democratização da Escola, Participação Comunitária e Cidadania Crítica. In: LIMA, Licínio C. Organização escolar e democracia radical: Paulo Freire e a governação democrática da escola pública. São Paulo: Cortez; Instituto Paulo Freire; 2000. http://www.acervodigital.unesp.br/bitstream/123456789/65259/4/u1_d26_v1_t03.pdf. Accessed $12 / 06 / 2019$.

[12] LOBE JUNIOR, Wilson Guilherme. Construção social do conceito de desenvolvimento sustentável: origens, sentido e alcance. In: NONES, Nelson; SILVEIRA, Adriana Bina da; HARTKE, Suzete Habitzreuter. Desafios para o direito empresarial. Blumenau: Legere; 2014, 219245.

[13] PEREIRA, João Victor Inácio. Sustentabilidade: diferentes perspectivas, um objectivo comum. $\begin{array}{lllll}\text { Economia Global e Gestão, Lisboa, 14(1), abr. } 2009 . & \end{array}$ http://www.scielo.mec.pt/scielo.php?script=sci_arttext\&pid=S087374442009000100008\&lng=pt\&nrm=iso. Accessed 12/07/2019.

[14] Pinto, José Marcelino de Rezende. A teoria da ação comunicativa de Jürgen Habermas: conceitos básicos e possibilidades de aplicação à administração escolar. Paidéia (Ribeirão Preto), (8-9), 1995, 77-96. https://dx.doi.org/10.1590/S0103-863X1995000100007. Accessed 12/07/2019.

*Corresponding author.

E-mail address: baadejoel@ gmail.com 